\title{
November Bull-Running in Stamford, Lincolnshire
}

\section{Martin W. Walsh}

The running of the bulls!-images of Pamplona, la Fiesta de San Firmin, the climactic scene of Hemingway's The Sun Also Rises. The quiet market-town of Stamford, Lincolnshire would hardly seem able to compete in exotic interest, and yet Stamford was the site of a bullrunning of considerable antiquity and longevity, and of quite pronounced carnivalesque character. This paper will attempt to chronicle this celebration, analyse in particular its carnivalesque features, and set it in the broader context of the medieval if not aboriginal festival calendar.

\section{A History of Suppression}

Let us begin our examination with the earliest full description of the event, from Richard Butcher's The Survey and Antiquitie of the Towne of STAMFORD, In the County of LINCOLNE published in 1646:

It is performed just the day six weekes before Christmas [13 November]. The Butchers of the Town at their own charge...provide the wildest Bull they can get, this Bull over night is had in to some Stable or Barne belonging to the Alderman, the next morning proclamation is made by the common Bell-man of the Town...that each one shut up their shops-doores and gates...That none have any Iron upon their Bull-clubs or other staffe which they pursue the Bull with. Which proclamation made and the Gates all shut up, the Bull is turned out of the Aldermans house, and then hivie, skivie, tag and rag, Men, Women and children of all sorts and sizes, with all the Dogs in the Town promiscuously running after him with their Bull-clubs spattering dirt in each others faces that one would think them to be so many Furies started out of Hell. (Burton 50) ${ }^{1}$

Butcher's puritanical bias is much in evidence-the spectacle provides "no pleasure except to such as take a pleasure in beastlinesse and mischief." He is particularly distressed that the local elite is also involved: "I have seen both Senatores majorum gentium, et matrones de eodem gradu, following this Bulling business." The Stamford BullRunning was clearly one of the class of folk practices heartily disparaged by the puritan sensibility. ${ }^{2}$ Its recorded history, indeed, is 


\section{Journal of Popular Culture}

largely one of attempted suppression, not completed however until the mid-nineteenth century.

Stamford's bull-run was vigorous enough to survive the Puritan era as were other unruly, dirt-loving, winter rites of Lincolnshire such as the Haxey "Hood-Game." A local antiquarian, the Rev. Francis Peck (16921743) wrote a pamphlet History of the Stamford Bull-Runnings in the early eighteenth century which must have legitimized the activity to some extent by giving it an antiquarian pedigree. ${ }^{3}$ Throughout the century of the Enlightenment, however, the bull-running was the subject of a protracted tug-of-war between the forces of reform and folk tradition. We find, for example, in the rector's accounts for the parish church of St. George, the following entry for 1737: "The Church Wardens...shall be allowed at the Bull-running yearly Ten Shillings, and no more, for their Expenses there." But the record of four years later, in 1741, indicates a minor victory for the reformers: "There shall not be allowed any money for...the Churchwardens, in case any is spent at the Bull-running in Stamford." In 1756, on the other hand, Robert Ridlington, tanner, alderman and ex-mayor, felt quite comfortable in leaving "half a crown...to each of five parishes annually" to defray the costs of "stopping gates and avenues to the town" during the annual event (Burton 51).

A poem written in 1781 under the pen-name "Delia" gives a clear indication of how the Age of Sensibility now viewed the old pasttime. The piece is entitled, "Ghost of the Running Bull at Stamford: A Reverie" and presents a dream vision of the beast, "his mangled form with mud and gore besmear'd," and then brings him forward to speak in his own voice (Harrod 419). Despite an overindulgence of the pathetic fallacy, the piece does appear to reflect an eye-witness account of the 13 November proceedings. It was reprinted by Harrod in his Antiquities of Stamford and St. Martin's compiled chiefly from the Annals of the Rev. Francis Peck (1785). Though Harrod does not condemn the bull-running outright, and in fact often waxes nostalgic about it, he nevertheless strongly intimates that not only is it a shadow of its former self, but also that its days are numbered. He mentions, for example, that unlike Butcher's day, no alderman now would even dream of offering his barn or stable for housing the animal before the festival.

In 1788 the reforming tendencies crystalized. The Mayor and the town Corporation, under the promptings of the Recorder, the Earl of Exeter, gave notice of intent to put down "a custom of such unparalleled cruelty to an innocent animal, and in all respects a Disgrace to Religion, Law, and Nature" (Burton 51-52). Harrod had ennumerated some of the more barbaric techniques of the "bullards" for goading a docile or tired 


\section{November Bull-Running in Stamford, Lincolnshire 235}

bull. They had "sawn off his horns, cut off his tail, fired a train of gunpowder along his back, and poured aqua fortis on the same" (Harrod, 192). "Delia" mentions firecrackers as well. Less as a remnant of Popery and its accomodated paganism, the Stamford Bull-Running was now opposed as an affront to bourgeois order, decency, and progressive civilization. The Stamford case illustrates the same processes which led to the taming of the medieval fair during the early industrial period, as analysed by Stallybrass and White in their important study The Politics and Poetics of Transgression (1981). We no longer have the united community as described by Butcher in the early seventeenth century, but rather an opposition now between a "high" and a "low" of Stamford society, or perhaps more accurately, between an expanding middle class and the lower orders, urban and rural, backed to some extent by more conservative elements of the local gentry. ${ }^{4}$

The reformers of 1788 were not above employing force. Special constables were called out by the Mayor and Corporation as well as a troop of dragoons to back them up. Lord Exeter and Sir Samuel Fludyer were "roughly treated" by the mob that year (Burton 52). Similar detachments were also dispatched in 1789 and 1790 but failed to stop the bullards, who through guile and coersion of their own managed to run as usual. Despite several arrests, no serious injuries were sustained during these years of reformist activism. The forces of suppression evidently thought it the wiser course to taper off their efforts and the bullards continued much as before. Indeed, bulls for the November and a supplementary Christmas-running became a form of electorial bribe, for both Liberals and Conservatives, in several of the Parliamentary elections of the early nineteenth century. The Conservatives even canvassed under a large banner painted with a bull until their clerical membership urged them, in 1831, to desist (Burton 53).

The archaic pastime was, however, losing impetus on its own. Unlike the event in Peck's time, the bull was not slaughtered after the run and its meat distributed to the bullards for their feast, with the head awarded as a kind of "champion's portion" to the most daring bull-rider. The whole event had devolved into a purely sporting occasion. The intervention of representatives from the Society for the Prevention of Cruelty to Animals in the early 1830 s brought matters finally to a head, aided as they were by Nonconformist elements within Stamford itself. Baptist minister J.F. Winks, for example, had printed a tract, The Bull Running at Stamford, a Transgression of the Divine Laws, and a Subject of Christian Grief; Being the Substance of a Sermon Delivered in the General Baptist Meeting-House, Stamford, on Lord's Day Evening, Nov.15,1829 (Malcolmson 56,104). This was the period, indeed, in 


\section{Journal of Popular Culture}

which the much wider practice of bull-baiting was sucessfully terminated throughout the North and Midlands.

The Stamford Bull-Running of 1836 , with some five to six thousand participants, marked the beginnning of the end. During the run an SPCA officer was assaulted and the windows of the house of Joseph Grant, a local opponent of the run, were smashed. At the Lent Assizes in Lincoln, several indictments were handed down for "conspiring, combining, and confederating together to beat, bait, wound, and torment a bull, and thereby to disturb the peace of the town of Stamford, and cause a riot and tumult" (Burton 55). A theater benefit, featuring Coleman's comedy John Bull, was held for the defendants and the substantial sum of $£ 100$ was raised. The trial at the Midsummer Assizes yielded a mix of guilty verdits and aquittals over the four counts and eight defendants, but an important precident had been set in that the judge ruled that venerable custom alone could not sanction an essentially "riotous" activity.

By November 1837 the Secretary of State, Lord John Russell was involved. (This was the first year of Victoria's reign, be it noted.) $\mathrm{He}$ gave the town magistrates permission to swear in over two hundred special constables. These were unable to stop a successful bull-running though they did prevent the streets from being blocked off in the usual way. The magistrates convened shortly thereafter and fines were imposed on a local laborer and a butcher, a clear indication that the most active supporters of the event were drawn chiefly from the lower ranks.

On 10 November of the following year detachments of the 14th Light Dragoons and the London Metropolitan Police arrived and proceeded to stake-out all the approach roads and favorite hiding places for the festival animal. The celebrants however came upon a bullock by accident as it was being transported through town, and they had their running as usual, with the added spice of all those infuriated troops. Stones and brickbats were hurled at the interfering military, chiefly by women and children it is recorded. Several townspeople were injured by the constables. The dragoons, forming up at St. Martin's Church and loading their weapons, managed to disperse the crowd without further incident. At the Borough Quarter Sessions in January 1839 four men were indicted for riotous assembly.

The 13 November of 1839 was a reprise of 1838 . Dragoon Guards, London police, and special constables stepped up surveillance and interdiction, and the bullards only managed to run an animal for a very brief period. A crowd of from three to four thousand threatened to "rescue" the bull from the confiscating officers but the forces of law and order managed this time to prevail. A memorial of 3 November 1840, 


\section{November Bull-Running in Stamford, Lincolnshire 237}

addressed to the Mayor and Corporation and signed by 670 Stamford citizens, finally conceded defeat. Having had to pay for the all the extra policing operations over the past four years had definitely hurt the Stamford rate-payers. They were not prepared any longer to defend an admittedly "illegal" activity. And so negative economics, that more efficient queller of folk practices, rather than high moral principles, finally ended the famous Stamford Bull-Run. (The SPCA, by the way, gained the royal $R$ in their name that year largely due to this Lincolnshire campaign.) Die-hards continued to sing the traditional "Bullard Song" in the approved locales of "riotous assembly," the taverns and the local playhouse, well past mid-century, but eventually even that disappeared (Philips 460).

\section{Carnivalesque Features}

The riotous events of the late 1780 s and the late 1830 s outlined above are merely a political extension, under the stimulus of attempted suppression, of an essentially riotous, carnivalesque folk-ritual. Let us now sketch out these essential features, with a view to recent "carnival theory." Butchers figure prominently in the records of the Stamford Bull-Run and butchers were often at the heart of urban carnivalesque performances from the Schembartlauf of fifteenth-century Nürnberg to the violent 1580 "Carnival in Romans" recently chronicled by Le Roy Ladurie. ${ }^{6}$ Reasons for this may be sought in the butchers' mastery of edged weapons, and, by extension, of sword dances and other warriorlike displays; in their presiding over the distribution of festival flesh and entrails; and in their essentially dirty and blood-tainted, "transgressive" profession.

In the Stamford context, conspicuous feats of bull-driving, goading, evading, and even riding ("boldly mount then on his back" enjoins the "Bullard Song") were obviously a major feature. One leading bull-driver whose name emerges from the confrontation of 1789 is, curiously, a woman, Ann Blades. She was dressed in a "smock-frock," that is, in the typical dress of the male farm-laborer. This conspicuous example of cross-dressing betrays the influence of the monde renversé topos so typical of carnivalesque performances. The "Bull-Woman," as she was called, was dressed from top to toe in blue, with a blue "bull-stick." She also took up a collection from the crowd. She was, then, a fully-fledged festival mask, the Woman-on-Top, whose very name, Bull-Woman, embodied the oxymoronic experience of Carnival. The general run of bullards are also described as wearing "uncouth and antic dresses, which they prepared with secret pride against the grand day" (Harrod 190). Thus they also participated to some degree in a state of mascarade, 


\section{Journal of Popular Culture}

though it would be perhaps too much to claim, from the surviving records, that the Bull-Woman served as kind of festival monarch for the bullards as a whole. A cup made from the horn of a bull run in 1799 does portray Bull-Woman "A.B." with an elaborate crown. Still, she may only have been an individual, eccentric contribution to the event. ${ }^{7}$ Her sexual inversion does, however, resonate with the "myth of origin" for Stamford's Bull-Running, recorded by Butcher as a venerable "tradition" and therefore going back well into sixteenth century.

In this patently fictional tale, the Norman suzerain, William, Earl Warenne, was looking out of his castle window one 13 November and spied out on the meadow two bulls fighting over a cow. The Stamford butchers then came with their dogs to part the bulls, enraging them further and causing them to stampede through the town tossing about men, women and children. Earl Warenne joined the wild mêlee on horseback and so enjoyed himself that he gave to the butchers of Stamford that piece of mating ground, thereafter called "Bull-meadow," on condition that they replicate the event yearly thereafter. In "Delia's" poem, "two beauteous gentle heifers," driven forth "to lure me on," prove the undoing of the noble beast. The Stamford Bull-Run then is, at one level, a deflected mating dance. The obvious sexual charge to the event in the macho display of the bullards was, however, rendered festively ambiguous by the prominent presence of the Bull-Woman and other inverted procedures.

Equally carnivalesque is the conspicuous use of "bull dirt." Butcher mentions it in his 1646 account, and Peck devoted much of his third chapter to the subject where he records the proverb, "He that gets no Bull-Dirt, gets no Christmas." He goes on to report that not only did the bullards deliberately besmear themselves but "when they put the Brute to Death, they gather his Ordure and present the Pomatum to those clean Faces that venture abroad in the Dusk of the Evening" (Gutch and Peacock 266). The transvaluation of filth, the reversal of a very fundamental taboo, is quite explicit in the Stamford case. Not simply the clods of earth churned up by the run but the very faeces of the animal become the inverted magical substance, here linked directly to the good cheer of Christmas and by extension to fertility, health, well-being in general. Such defilement is typical of the more atavistic Carnival celebrations still practiced in parts of Europe. For example, in Languedoc the savage, bulging, befeathered Pailhasses of Cournonterral forcibly wash their captives in river slit. ${ }^{8}$ In Stamford the bullards were a similar species of Wildman, going through some process of identification with their victim, the raging bull. But it must be pointed out, however, that unlike the Pailhasses, the bullards do not seem to 


\section{November Bull-Running in Stamford, Lincolnshire 239}

have been rigidly segregated by gender or even by age, since women and children ("hivie, skivy, tag, and rag") participated in the run-as well as in the nineteenth-century riots against the police.

The Stamford Bull-Running possessed as well a full range of carnivalesque accoutrements: elements of costuming, props (the bullclubs), and the employment of a special effigy, dubbed "St. Andrew," which travelled about in a wheelbarrow. When slung by ropes between two facing windows on a street it was employed as an evasive target to further torment the bull. Why it was called St. Andrew is unclear. Andrew is also a November saint but his feast (30 November) is a good fortnight after the Stamford run. Perhaps the puppet was simply built in the X-like configuration of the familiar St. Andrew's Cross. There was also a particular call, "Hoy, Bull, Hoy" practiced by the boys of the town weeks in advance of the event, and we have had occasion to quote the festival anthem, the "Song of the Stamford Bullards," whose tune one antiquarian dates back to the reign of Charles I (Phillips 460). As well as being an important source for many of the specialized "turns" within the overall event, the song also refers to the Earl Warenne legend.

That the Stamford Bull-Running achieved the "liminality" Victor Turner finds characteristic of rites of reversal is amply demonstrated by the bullards themselves. Peck records a speech from the 1720s:

\section{"Speech of a Notable Bullard of Forty Moons Ago"}

On this Day there is no King in Stamford; we are every one of us High and Mighty. Lords of the united Parishes in a General Bull-running...We are every one of us a Lord Paramount, a Lord of Rule and Misrule, a King in Stamford...I most humbly advise...that there be friendly Participation of the Flesh and Puddings of the deceased Beast, and that the Great Gut or Pudding, commonly known by the name of Tom Hodge, be given to the most Worthy Adventurer. (Gutch and Peacock 266)

Conspicuous consumption of flesh, a utopian kingdom where rule and misrule alternate, a saying: "The bull may die, but he cannot be killed" clearly illustrating the eternity of Bakhtin's "grotesque body"we have, then, all the features of a classic Carnivale, not at the beginning of Lent, however, but at the beginning of Advent. We have now to determine the reason for this in the historical facts behind the Stamford Bull-Running. 


\section{Journal of Popular Culture}

\section{Martlemas Beefe}

The Stamford antiquary George Burton, true to earlier scholarly form, was fond of rehearsing various theories for the origin of the bullrunning, often on the most circumstantial of evidence. It might have been a Roman practice since Stamford was on a branch of the ancient Ermine Street and had a Roman encampment nearby. It might have been a Danish rite since Stamford was one of the five centers of power in the Danelaw. It could be Norman, given the Earl Warenne legend-although the most this actually tells us is that Stamford's folk-imagination (if we can talk of such a thing) could not imagine anything earlier than the reign of King John.

There is, however, an isolated medieval record that seems to place the bull-run early in the fourteenth-century. In the ordinaces of English guilds collected by Toulmin Smith we find a 1389 return from Stamford's Guild of St. Martin in which it is stated that "on the feast of St. Martin (11 November), this gild, by custom beyond reach of memory, has a bull; which bull is hunted [not baited ] by dogs, and then sold; whereupon the bretheren and sisteren sit down to feast" (192). This guild was attached to the important parish church of St. Martin, a Norman foundation. The Guild's founder is unknown (the Warenne family?), but it appears to have been established before the thirteenth year of Edward II, 1329, and to have lasted up to the second year of the reign of Edward VI, that is, until the middle of the sixteenth century. Its last incumbant was a "meanly learned" commoner by the name of Thomas Pocket (Burton 188-89).

Francis Peck in his history of the bull-running assumed that the event mentioned in the Guild of St. Martin ordinance was the direct and immediate ancestor of the event as described by Butcher in the seventeenth century. Certainly the medieval Guild sponsored something very like a bull-run and at just the right time, Martinmas. If the Guild's sponsorship of the November activities continued up to 1549 then there is less than a hundred year gap until Butcher's full description which, given the general conversatism of folk practices, is not a very significant break in the record. The modern date for the run, 13 November (Butcher's "just the day six weeks before Christmas") is well within the formerly important Octave of St. Martin (11-18 November) and moreover belongs to St. Brice who was Martin's designated successor as Bishop of Tours. ${ }^{9}$ We are clearly still within the orbit of Martinmas. What is lacking in the chain of evidence are the butchers who figure so prominently in the late records, even down to the fines imposed in 1837. What we might well have here is a common process involved in popular rites: the necessary assistants (here the butchers) eventually become the 


\section{November Bull-Running in Stamford, Lincolnshire 241}

guardians of the tradition, its very raison d'etre, as the event, over generations, loses connection with the local elites. If the Stamford butchers were an important component of (or simply employed by) the medieval Guild of St. Martin, then the ur-event might well have proceeded according to this sequence: the guild procures a bull, the bullrun, slaughter of the animal, feasting upon its flesh by the confraternity, with perhaps further distribution to the needy in the spirit of the "Charity of St. Martin."

Not being able to forge this missing link myself at the present time, I will only endorse Peck's surmise, but point as well to the fact that Martinmas traditionally marked the slaughtering time for the beef, swine and geese not being maintained through the winter on stored feed. Throughout the north November was the "slaughtering month," witness the Anglo-Saxon blut monath, the Early Modern Dutch Slachtmaand and the Danish slagtemaned. "Martin Martlemasbeefe" was one of godfathers of Gluttony in Marlowe's Doctor Faustus and Sir John Falstaff himself was referred to as "the martlemas" in 2 Henry $I V$, indicating the proverbial strength of the association in England. ${ }^{10}$ Johannes Boemus Aubanus records the following practice for fifteenthcentury Würzburg:

There is not one throughout all the whole country be hee neuer so needy, or neuer so niggard but vpon Saint Martins day hee will haue some roste meate, or boiled meat, and it be but Hogs intrailes, or Calues intrailes, \& glut themselves with wine, for then they tast of their new wines from which till that time they haue abstained; and all their housholds drinke wine with them...then haue they their publicke shews and pastimes, as to haue two or three Boares put into a place together, and to behold them fight and teare one another with their tuskes till their guttes traile about their heeles, deuiding the flesh when the Boares bee dead, some to the common people and some to the Magistrates (284).

This could well represent the survival of ancient Frankish pastimes as recorded by Gregory of Tours (469). Analogous practices are recorded by William FitzStephen for Norman London (ante 1183):

In winter on almost every feast-day before dinner either foaming boars and hogs, armed with 'tusks lightning swift,' themselves soon to be bacon, fight for their lives, or fat bulls with butting horns, or huge bears, do combat to the death against hounds let loose upon them (58).

These are obviously close cognates to the Stamford event. Blood sport, followed by slaughter (presuming the presence of butchers), and the 


\section{Journal of Popular Culture}

sharing of meat, then, are the common features of these communal Martinmas celebrations.

Martinmas, then, was not only a meat-and-wine feast at the threshold of Winter, all under the Saturnalian sign of the Saint's famous shared mantle, but also the occasion for more expansive festivities. It marked the period when autumn's tasks were finally complete. It was simultaneously the last harvest celebration and the first winter revel. It was the last chance to feast and carry on before the penitential season of Advent, second only to that of Lent. Elsewhere I have examined the Feast of St. Martin as a kind of "shadow Carnival," at the other end of the winter revelling season from the better known holiday, but mirroring it in many fundamental respects. Perhaps it even preceded Carnival as the topsy-turvy kingdom, given the very early records of Martinmas carousal and the fairly late development of an agriculture that allowed for widespread festival consumption at the end rather than at the beginning of winter."

If the Stamford Bull-Running was, as seems most likely, a specifically Martinmas event of the high medieval period, the carnivalesque features here examined would be of a piece with secular Martinmas celebration elsewhere in northern Europe. We cannot legitimately push the date of the bull-run much before the early fourteenth century. One modern local historian assumes that the Warenne family supplied the bull before the foundation of the Guild of St. Martin, thus accounting for the legend of origin. This is certainly a possiblity, though no proof is offered (Platts 280). One particular feature of the Stamford event does, however, strongly suggest that it is considerably older than the high Middle Ages. We have had occasion to quote the "Song of the Stamford Bullards." The fourth stanza exhorts the bullards to "Come take him by the tail, boys-/Bridge, bridge him if you can" (Burton 69). "Bridging" was the process of tumbling the bull by main force from Stamford bridge into the River Welland. As "Delia" describes the process:

\footnotetext{
Many uniting rear'd me up,

They heav' $d$ me as a beam

Over the bridge with violence

And plung'd me in the stream;
}

Rous'd by the current and the fall

Then madness seiz'd my brain,

I swam to shore defying all,

And foaming rac'd the plain.

(Harrod 422) 
November Bull-Running in Stamford, Lincolnshire 243

Significant Dates for the Stamford Bull-Running:

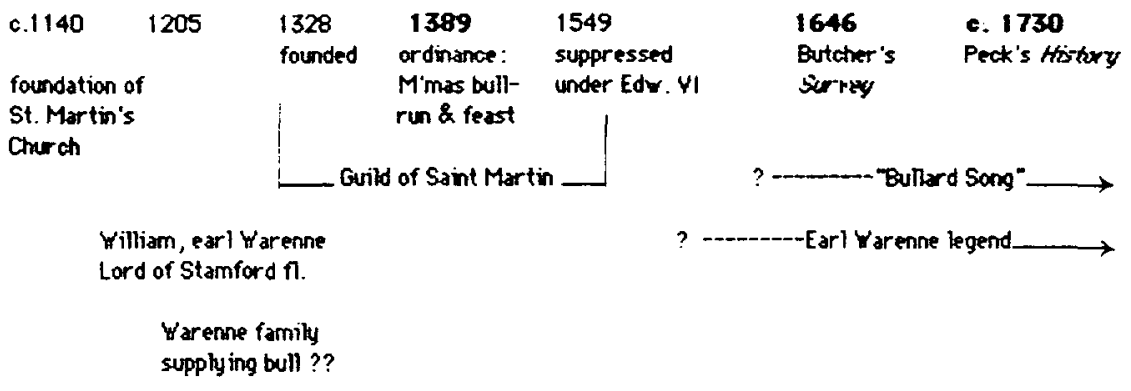

\begin{tabular}{|c|c|c|c|c|c|}
\hline $\begin{array}{l}1737-41 \\
\text { st George's } \\
\text { rector's } \\
\text { accounts }\end{array}$ & $\begin{array}{l}\text { Ridhington } \\
\text { bequest }\end{array}$ & $\begin{array}{l}1781 \\
\text { protest } \\
\text { poem by } \\
\text { Deha" }\end{array}$ & $\begin{array}{l}1785 \\
\text { Harrod's } \\
\text { Anfivitites af } \\
\text { Stanisins }\end{array}$ & $1788 \ldots 1789 \ldots 1790$ & $\begin{array}{l}1799 \\
\text { "A.E." } \\
\text { cup }\end{array}$ \\
\hline
\end{tabular}

"Bullaro Song"

$\begin{array}{ll}1829 & 1831 \\ \text { Yink's } & \text { Bull flag } \\ \text { sermon } & \text { dropped }\end{array}$

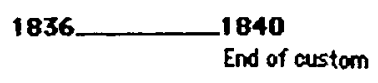

SPCA agitation

second suppression campaign

Bullard Song" 


\section{Journal of Popular Culture}

This medieval stone bridge united the two main sections of the city, the town center with the important parish of St. Martin, formerly the Lincolnshire and Northhamptonshire divisions of Stamford (Wright 101).

This river-boundary feature is found again in the only other significant bull-running to survive in the English record. Capturing a bull with a soaped tail was part of the festivities of Assumption Day (15 August) in Tutbury, Staffordshire, the "Pipers at Tedbury Bull-running" having been mentioned in a play of $1636 .{ }^{12}$ If a bunch of the bull's hair could be cut off before it crossed the River Dove into Derbyshire it became the property of the festival monarch, the "King of the Minstrels," otherwise it reverted to the donor, the Prior of Tutbury, later, the Duke of Devonshire. These associations of bull-running with river boundaries suggest something fairly archaic-early medieval or perhaps even aboriginal, the power associated with river fords being common in Celtic mythology. While it might be tempting to see a pagan survival behind the medieval Martinmas context of the Stamford event, such a temptation must be resisted until more substantial evidence can be found. As it stands, however, the November carnival of the Stamford Bull-Running has a probable history of over five centuries-half a millenium-a fairly remarkable pedigree for any folk ritual performance.

\section{Notes}

'Butcher's passage is quoted repeatedly in the literature on Stamford. Principal sources for the modern history of the bull-running are Harrod's Antiquities of Stamford and St. Martin's (190-94, 419-20) and Burton's "Bullrunning" and "Guild of Saint Martin" entries in Chronology of Stamford compiled only six years after the suppression of the custom. The most thorough recent discussion is found in Malcolmson's Popular Recreations in English Society, 1700-1850 (127-35). Further materials can be found in the Phillips Collection in the Stamford Town Hall, which also possesses two early oil paintings of the event.

${ }^{2}$ See esp. David Underdown, Revel, Riot and Rebellion: Popular Politics and Culture in England, 1603-1660 (Oxford: Oxford University Press,1985) and Leah S. Marcus, The Politics of Mirth: Jonson, Herrick, Milton, Marvell and the Defence of Old Holiday Pastimes (Chicago: University of Chicago Press, 1986).

${ }^{3}$ This locally produced pamphlet may no longer exist. Harrod in 1785 stated that he "was never so happy as to meet with it" (191). Gutch and Peacock, however, quote liberally from a handwritten copy. 


\section{November Bull-Running in Stamford, Lincolnshire 245}

"Tensions between the lower orders and their "betters" over the bull-running were perhaps aggravated by the disappointing local results of the Reform Bill of 1832. Due to a peculiarity of reapportionment, whereby the district of St. Martin's was joined to Stamford proper, the power of the earls of Exeter, long opponents of the run, was consolidated rather than reduced (Wright 11-12).

sParticularly Stallybrass and White's Introduction with their corrections to and amplifications of Mikhail Bakhtin's influential Rabelais and His World (1965). See also Victor Turner, From Ritual to Theatre: The Human Seriousness of Play (New York: Performing Arts Journal Publications,1982).

'Hans-Ulrich Roller, Der Nürnberger Schembartlauf (Tübingen: Vereinigung für Volkskund, 1965) and Samuel Leslie Sumberg, The Nuremberg Schembart Carnival (New York: Columbia University Press, 1941). Emmanuel La Roy Ladurie, Carnival in Romans, trans. Mary Feeny (New York: George Braziller, 1979).

${ }^{7} \mathrm{Cf}$ the character known as "Bull-riding Betty" who rode in the bulls for baiting in Mere, Wiltshire, c.1820. Antiquary 27 (1893): 235. Ann Blades may be the imposing figure in blue presiding over the event in a painting of the bullrun, c. 1800, hanging in the Stamford Town Hall. There she is not dressed in the "smock-frock" but in an ample gentlewoman's dress with plumed hat and cane.

${ }^{8}$ Daniel Fabre and Charles Camberoque, La fête en Languedoc (Toulouse: Edouard Privat, 1977), chap. 4. The Stamford event escaped the notice of John G. Bourke in his classic Scatalogic Rites of All Nations (1891), but the use of bull dung is not unknown among warrior types. A hero in the first book of the Mahabarata, for example, eats the ambrosial dung of a giant bull to empower himself for his subsequent adventures.

'St. Brice's Day was also the date, in 1002, of a supposed massacre of feasting Danes by King Ethelred according to the Anglo-Saxon Chronicle. Some confused recollection of November as the "slaughter month?"

${ }^{10}$ It is perhaps not pure coincidence that Birmingham's "Bull Ring" (the iron ring for restraining a bull rather than an arena) was located in the parish of St. Martin and was the site of one of the last full bull-baitings in England, c.1817. Notes and Queries, 5th ser.,12 (1879): 455. The two "storers," who provided a common bull and enjoyed the use of a pasture called the "Bullgrass" on the manor of Whitlesea, Isle of Ely, Cambs., were chosen on the "Sunday next after the feast of St. Martin." Thomas Blount, Fragmenta Antiquitatis: or, Ancient Tenures of Land and Jocular Customs of Manors (London: S. Brooke, 1815), 576.

"This hypothesis is expanded in two articles by the author, "Martin of Tours: A Patron Saint of Medieval Comedy" in Saints: Studies in Hagiography (Acta XIV), ed. Sandro Sticca (Binghamton: Medieval \& Renaissance Texts \& Studies, 1996, 283-315) and "Martinsnacht as an Early Locus of Carnivalesque Activity," Medieval Folklore 3 (1994): 127-65. 


\section{Journal of Popular Culture}

${ }^{12}$ For the Tutbury Bull-Running see Robert Plot, The Natural History of Staffordshire (Oxford,1686), 436-40; Samuel Lewis, A Topographical Dictionary of England (London: S. Lewis \& Co.,1831), 4: 340-41; and Blount's, Fragmenta Antiquitatis. Play reference from Act V, The Vow-Breaker or, the Faire Maide of Clifton: "Hee'l keepe more stir with the hobby-Horse than he did with the Pipers at Tedbury Bull-running; provide thou for the Dragon, and leave me for a hobby-Horse" (Sampson 69). Burton assumed this referred to Tetbury, Gloustershire and thus produced a third English bullrunning (Old Lincolnshire 90). No such corroboration is found in the Topographical Dictionary . Given the rather loose orthography of the period, it would make more sense to equate the play's "Tedbury" with Tutbury, Staffs. where there were both minstrels and a bull-running. See also: "A new Ballad of bold Robin Hood: shewing his Birth, Breeding, Valour and Marriage at Titbury Bull-running" (where "the bag pipes baited the bull") for yet another variant spelling, in Stebbing Shaw, The History and Antiquities of Staffordshire (London,1798,1, part ii, 55). Tutbury's Bull-Running was suppressed in 1778. Wisbech, Cambs. (25 miles from Stamford) staged the occasional Shrove Tuesday bull-running until about 1792 .

\section{Works Cited}

Aubanus, Johannes Boemus. The Manners, Lawes, and Cvstoms of All Nations collected out of the best Writers. London: George Eld, 1611.

Burton, George. Chronology of Stamford . Stamford: Robert Bagley,1846. "Bull-Running and Bull-Rings," Old Lincolnshire 1 (1883): 90-95; 13435.

FitzStephen, William. "A Description of London." Norman London. Ed. and trans. F. Donald Logan. New York: Italica P,1990.

Gregory of Tours. History of the Franks. Trans. Lewis Thorpe. London: Penguin, 1974.

Gutch, Eliza and Mabel Peacock. County Folklore 5: Examples of Printed FolkLore concerning Lincolnshire. London: David Nutt for the Folk-Lore Society, 1908.

Harrod, W. The Antiquities of Stamford and St. Martin's compiled chiefly from the Annals of the Rev. Francis Peck. Stamford: W. Harrod, 1785.

Malcolmson, Robert W. Popular Recreations in English Society, 1700-1850. Cambridge: Cambridge UP,1973.

Peacock, Mabel. "Notes on the Stamford Bull-Running," Folk-Lore 15 (1904):199-202.

Phillips, J. "Bull Song at Stamford." Notes and Queries, 2nd ser., 23 (1856): 460 , in reponse to $N Q 20$ (1856): 392. 
Platts, Graham. Land and People in Medieval Lincolnshire. Lincoln: History of Lincolnshire Committee, 1985.

Sampson, William. William Sampson's Vow-Breaker [1636]. Ed. Hans Wallrath. Louvain: A. Uystpruyst, 1914.

Smith, Toulmin and Lucy Toulmin Smith, eds. English Gilds: The Original Ordinances of More Than One Hundred Early English Gilds. Early English Text Society O.S. 40 [1870]. London: Oxford UP, 1963.

Stallybrass, Peter and Alon White. The Politics and Poetics of Transgression London: Metheun, 1986.

Wright, Neil R. Lincolnshire Towns and Industry, 1700-1914. Lincoln: History of Lincolnshire Committee, 1982.

Martin W. Walsh is a Professor in the Department of Theater and Drama and the Residential College, University of Michigan, Ann Arbor, MI. 